\title{
DZIALANIA POWIATOWYCH CENTRÓW POMOCY RODZINIE W OBSZARZE WSPARCIA CUDZOZIEMCÓW
}

\begin{abstract}
Streszczenie
Niniejszy artykuł podejmuje rzadko opisywany w literaturze temat indywidualnych programów integracji cudzoziemców w Polsce. Scharakteryzowano teoretyczne aspekty pojęć cudzoziemcy oraz uchodźcy. Poruszono także kwestię prawną ubiegania się oraz udzielania ochrony międzynarodowej w Polsce, a także uprawnień do pobierania świadczeń pomocy społecznej. W artykule zaprezentowano wyniki badań przeprowadzonych wśród pracowników socjalnych z wybranych powiatowych centr pomocy rodzinie. Konkluzją rozważań są wnioski dotyczące realizacji indywidualnych programów integracji jako formy wsparcia cudzoziemców.
\end{abstract}

Słowa kluczowe: cudzoziemcy, uchodźcy, indywidualne programy integracji.

\section{Wprowadzenie}

Uchodźctwo jest ważnym problemem społecznym, który wciąż nie został dostatecznie zbadany. Artykuł odnosi się do badań przeprowadzonych przez autorkę w okresie kwiecień-maj 2020, dotyczących realizacji indywidualnych programów integracji cudzoziemców w wybranych powiatowych centrach pomocy rodzinie. Głównym celem teoretycznym badań była próba określenia roli i skuteczności indywidualnych programów integracji w procesie wsparcia cudzoziemców i uchodźców. Za cel praktyczny przyjęto próbę sformułowania wniosków dla praktyki realizowania indywidualnych programów integracji przez pracowników socjalnych. Szczegółowo przeanalizowano także skalę praktycznego realizowania indywidual- 
nych programów integracji przez powiatowe centra pomocy rodzinie; cechy socjodemograficzne cudzoziemców najczęściej korzystających z indywidualnych programów integracji; poziom przygotowania pracowników socjalnych do pracy z cudzoziemcami; ocenę skuteczności indywidualnych programów integracji; problemy i trudności napotykane przez pracowników socjalnych realizujących indywidualne programy integracji; a także wyzwania związane $\mathrm{z}$ funkcjonowaniem systemu udzielania pomocy cudzoziemcom i uchodźcom. Z kolei hipoteza stawiana w niniejszym artykule brzmi: Jaka jest rola i skuteczność indywidualnych programów integracji w procesie wsparcia cudzoziemców i uchodźców?

\section{Cudzoziemcy i uchodźcy - aspekty definicyjne i prawne}

Problem migracji i uchodźctwa jest tematem zainteresowań badaczy już od dawna. Główny Urząd Statystyczny podał, iż 31 grudnia 2019 r. w Polsce mieszkało 2106101 cudzoziemców (GUS, 2020). Skala zjawiska migracji jest więc ogromna. Artykuł 2 ustawy z dnia 12 grudnia 2013 r. o cudzoziemcach (Dz. U. z 2013r., poz. 1650) określa cudzoziemca jako każdego, kto nie posiada obywatelstwa polskiego. Migracje są cechą charakterystyczną ludzi od najstarszych czasów. Rozumiane były i są jako wędrówki ludzi. Migrację można rozpatrywać na dwóch płaszczyznach - poziomej, definiując jako względnie stałą zmianę miejsca zamieszkania, która dokonywana jest w przestrzeni geograficznej oraz pionowej związaną ze zmianą usytuowania w strukturze społecznej (Krawczyńska-Butrym, 2009, s. 11). Migracje wewnętrzne w Polsce przez wiele lat związane były z uprzemysłowieniem oraz szybkim rozwojem infrastrukturalnym miast, co powodowało przepływ ludzi ze wsi do miast z pobudek czysto ekonomicznych. Oprócz fizycznej zmiany otoczenia niesie to za sobą zmianę położenia społecznego, czyli dostępu do pracy, opieki zdrowotnej, świadczeń socjalnych, edukacji oraz kultury. Migracja zewnętrzna wiąże się z przekroczeniem granicy państwa, a podzielić ją można na emigrację oraz imigrację. Emigracją jest opuszczenie swojego kraju i osiedlenie się w innym, obcym państwie. Taka osoba staje się emigrantem. Imigracją nazywany jest przyjazd $\mathrm{z}$ innego kraju i osiedlenie się w nowym miejscu. Taka osoba staje się imigrantem w kraju, który go przyjmuje. Status uchodźcy reguluje Konwencja Genewska z 1951 roku, a także jej modyfikacja, która została zawarta w Protokole Nowojorskim z 1967 roku. Artykuł 1 Konwencji Genewskiej jako uchodźcę definiuje osobę, która „na skutek uzasadnionej obawy przed prześladowaniem z powodu swojej rasy, religii, narodowości, przekonań politycznych lub przynależności do określonej grupy społecznej lub z powodu przekonań politycznych przebywa poza granicami państwa, którego jest obywatelem, i nie 
może lub nie chce z powodu tych obaw korzystać z ochrony tego państwa, albo która nie ma żadnego obywatelstwa i znajdując się, na skutek podobnych zdarzeń, poza państwem swojego dawnego stałego zamieszkania nie może lub nie chce z powodu tych obaw powrócić do tego państwa” (Dz. U. z 1991, nr 119, poz. 515). Uchodźcy stanowią więc specyficzną grupę cudzoziemców, którzy uciekają ze swojego państwa pochodzenia w strachu i obawie przed doznaniem krzywdy w formie prześladowania, narażenia na utratę ochrony podstawowych praw człowieka. Warto również podkreślić, iż cudzoziemiec formalnie staje się uchodźcą dopiero po przejściu długiej procedury, w czasie której badane są przyczyny jego ucieczki, a następnie wydawana jest decyzja o nadaniu statusu uchodźcy. Nie do końca sama przeszłość osoby czyni ją uchodźcą, a raczej sposób, w jaki chce zalegalizować swój pobyt w danym kraju. Złożenie wniosku o udzielenie ochrony międzynarodowej w formie statusu uchodźcy natychmiastowo legalizuje pobyt w Polsce oraz zapewnia pobyt w ośrodku dla cudzoziemców, a wraz z nim dach nad głową, wyżywienie, opiekę medyczną, wsparcie emocjonalne, szkołę dla dzieci, a także wsparcie podczas całego procesu. Dla niektórych grup migrantów ta strategia jest ostatecznością i korzystają z niej dopiero, gdy inne próby zalegalizowania swojego pobytu nie przyniosły żadnego efektu. Każdy uchodźca jest więc migrantem, jednak nie każdy migrant jest uchodźcą. Cudzoziemcem będzie zaś każdy migrant i każdy uchodźca dla kraju, w którym się znajdują.

Ustawa z dnia 13 czerwca 2003 roku o udzielaniu cudzoziemcom ochrony na terytorium Rzeczypospolitej Polskiej (Dz. U. z 2003 r., nr 128, poz. 1176) określa warunki, zasady oraz tryb udzielania cudzoziemcom ochrony na terytorium Rzeczypospolitej Polskiej, a także właściwe organy w tych sprawach. Na terytorium Rzeczypospolitej Polskiej cudzoziemcowi udziela się ochrony przez:

- nadanie statusu uchodźcy;

- udzielenie ochrony uzupełniającej;

- udzielenie azylu;

- udzielenie zgody na pobyt tolerowany;

- udzielenie ochrony czasowej (Dz. U. z 2003 r., nr 128, poz. 1176, art. 3).

Ustawa szczegółowo opisuje pobudki przemawiające za nadaniem statusu uchodźcy, uściślając, iż prześladowanie, przed którym ucieka ubiegający się o status, musi stanowić poważne naruszenie podstawowych praw człowieka; być działaniem lub zaniechaniem naruszającym prawa człowieka w sposób równie dotkliwy, co prześladowanie. Za prześladowanie uznaje się: użycie przemocy psychicznej, fizycznej bądź wykorzystanie seksualne; stosowanie środków prawnych, administracyjnych czy sądowych, które są dyskryminujące; postępowanie karne, którego charakter jest nieproporcjonalny; brak możliwości skorzystania z prawa odwołania się przy powyższej sytuacji; działanie przeciwko komuś ze względu na 
jego płeć bądź niepełnoletni wiek; a także próba ukarania w przypadku odmowy odbycia służby wojskowej w czasie konfliktu (Dz. U. z 2003 r., nr 128, poz. 1176, art. 13). Ochrona uzupełniająca jest formą ochrony cudzoziemca w przypadku, kiedy nie spełnia on przesłanek do udzielenia statusu uchodźcy, jednak jego powrót do kraju zamieszkania może narazić go na doznanie krzywdy poprzez: tortury, karanie, niehumanitarne traktowanie; wydanie kary śmierci bądź wydanie egzekucji; w przypadku konfliktu zbrojnego zagrożenie dla życia lub zdrowia ludności cywilnej. Azyl jest kolejną formą ochrony międzynarodowej, o którą może ubiegać się obcokrajowiec. Na wniosek cudzoziemca, można udzielić mu azylu w Polsce, kiedy przemawia za tym ważny interes Rzeczypospolitej Polskiej, a także kiedy jest to niezbędne do zapewnienia mu ochrony. Osobie, której udzielono azylu, zezwala się na osiedlenie. Wnioskując o azyl należy określić istotne zdarzenia, które są przyczyną ubiegania się o tę formę wsparcia. Nie ma możliwości zobowiązania do opuszczenia terytorium Polski cudzoziemca, który uzyskał azyl. Decyzja o wydaleniu z kraju możliwa jest tylko w przypadku wcześniejszego pozbawienia azylu. Zgoda na pobyt tolerowany to następna forma ochrony, która wydawana jest, jeżeli wydalenie cudzoziemca wiąże się z możliwością odesłania go do kraju, w którym jego życie, prawo do wolności i bezpieczeństwa byłoby zagrożone; gdzie istnieje ryzyko poddania go torturom bądź nieludzkiemu, poniżającemu traktowaniu, czy też miałby być zmuszany do pracy i pozbawiony możliwości rzetelnego procesu sądowego. Zgoda na pobyt tolerowany wydawana jest także jeżeli odesłanie cudzoziemca do kraju pochodzenia naruszałoby prawo do życia w rodzinie lub prawa dziecka w znaczącym stopniu. Inna przesłanka do udzielenia zgody to sytuacja, gdy deportacja cudzoziemca mogłaby się odbyć jedynie do państwa, gdzie wydalenie jest niedopuszczalne bazując na orzeczeniu sądu, bądź na podstawie rozstrzygnięcia ministra sprawiedliwości. Osobie, której udzielono zgody na pobyt tolerowany, przysługują prawa cudzoziemca jak w przypadku uzyskania zezwolenia na czas określony. Otrzymuje on kartę pobytu, która ważna jest przez rok. Ostatnia z form ochrony to ochrona czasowa, która udzielana jest cudzoziemcom, którzy masowo przybywają do Polski, a swój kraj pochodzenia opuścili z powodu wojny, konfliktów etnicznych, inwazji, naruszeń praw człowieka, a przy udzielaniu tego rodzaju pomocy nie ma znaczenie charakter przybycia do Polski. Pomoc ta udzielana jest do momentu, kiedy powrót cudzoziemca do jego poprzedniego miejsca zamieszkania staje się możliwy, jednak pomoc w tej formie nie trwa dłużej niż rok (Dz. U. z 2003 r., nr 128, poz. 1176, art. 106). 


\section{Indywidualny program integracji jako forma pomocy dla cudzoziemców}

Cudzoziemcom zamieszkałym i przebywającym w Polsce przysługuje prawo do korzystania ze świadczeń pomocy społecznej, jeżeli ich pobyt opiera się na zezwoleniu na pobyt stały, pobyt czasowy, pobyt rezydenta długoterminowego Unii Europejskiej, a także uzyskaniu statusu uchodźcy bądź ochrony uzupełniającej. Pobyt tolerowany oraz pobyt ze względów humanitarnych uprawnia do skorzystania pomocy jedynie w formie niezbędnego ubrania, posiłku, schronienia oraz zasiłku celowego (Dz. U. z 2019 r. poz. 1690, art. 5). Zgodnie z definicją pomocy społecznej, jako instytucji polityki społecznej państwa, której celem jest umożliwienie osobom i rodzinom przezwyciężanie trudnych sytuacji życiowych, cudzoziemcy przebywający w Polsce na określonych ustawowo warunkach, w sytuacjach trudnych, kryzysowych, z którymi nie są w stanie poradzić sobie własnymi zasobami, mogą liczyć na wsparcie i pomoc od państwa. Pomoc w formie indywidualnego programu integracji przysługuje wąskiej grupie cudzoziemców. Są to osoby, które uzyskały status uchodźcy lub ochronę uzupełniają lub też zezwolenie na pobyt czasowy na warunkach określonych w art. 159 ust. 1 pkt 1 lit. c lub d ustawy z dnia 12 grudnia 2013 r. o cudzoziemcach (Dz. U. z 2019 r. poz. 1690, art. 91, pkt 1). Jednostką odpowiedzialną za realizację tego zadania jest powiat (Dz. U. z 2019 r. poz. 1690, art. 20). Indywidualny program integracji można określić jako jeden z instrumentów pomocy społecznej, który stanowi formę jej realizacji, a którego celem jest wspieranie procesu integracji cudzoziemców, którzy przebywają w Polsce i uzyskali ochronę uzupełniającą bądź status uchodźcy (Misztal, 2013, s. 354). Program jest formą dwustronnej umowy, zawieranej przez zainteresowanego cudzoziemca oraz odpowiednie powiatowe centrum pomocy rodzinie, zatwierdzanej przez wojewodę. Umowa ta szczegółowo określa i definiuje zakres, wysokość, czas trwania oraz formy pomocy i wsparcia, a także ich warunki. Czynniki te są zależne od indywidualnej sytuacji życiowej strony oraz jej rodziny. Powiatowe centrum pomocy rodziny zobowiązane jest do:

- omówienia oraz wyjaśnienia cudzoziemcowi wszystkich informacji zawartych w umowie programu, wraz z warunkami wstrzymania lub odmowy udzielenia;

- wsparcia w znalezieniu możliwości zamieszkania, także w mieszkaniu chronionym;

- świadczenia pracy socjalnej na rzecz interesanta;

- współpracy oraz wsparcia w kontaktach i relacjach z najbliższym otoczeniem oraz nawiązywaniem kontaktu ze środowiskiem lokalnym, także z najbliższym dla miejsca zamieszkania osoby ośrodkiem pomocy społecznej; 
- również do realizacji innych, indywidualnie ustalonych działań, wynikających z sytuacji życiowej cudzoziemca (Dz. U. z 2019 r. poz. 1690, art. 93).

Plan i rodzaj pomocy ustalany jest w oparciu o ocenę sytuacji życiowej samego cudzoziemca oraz sytuacji życiowej jego rodziny. Oceny tej dokonują pracownicy centrum. Warunki udzielania pomocy muszą zostać przedstawione cudzoziemcowi jeszcze przed opracowaniem treści programu. Na centrum pomocy spoczywa obowiązek ustalenia instytucji pomocowych, których wsparcie będzie niezbędne podczas realizacji programu, podając także zakres ich działań (Dz. U. z 2019 r. poz. 1690). Centrum pomocy zobowiązane jest do wskazania pracownika, który będzie realizatorem programu, a więc swego rodzaju opiekunem projektu, którego obowiązkiem jest uzgodnienie oraz wspieranie osoby przez cały okres objęcia programem (Dz. U. z 2019 r. poz. 1690, art. 93). Jednocześnie na cudzoziemca ustawa narzuca obowiązek:

- dokonania meldunku w miejscu zamieszkania;

- w sytuacji niewystarczającej znajomości języka polskiego do obowiązkowego uczestnictwa w kursie językowym;

- dokonania rejestracji w powiatowym urzędzie pracy oraz późniejszego aktywnego poszukiwania zatrudnienia;

- stałej współpracy oraz kontaktowania się z pracownikiem realizującym program, w terminach przez niego ustalonych, jednak nie rzadziej niż 2 razy w miesiącu;

- przestrzegania wszystkich, przyjętych w programie ustaleń i zobowiązań;

- realizacji innych, uzgodnionych wraz z pracownikiem realizującym program działań, które wynikają z indywidualnej sytuacji odbiorcy programu (Dz. U. z 2019 r. poz. 1690, art. 93).

Po ustaleniu warunków oraz zasad indywidualnego programu integracji przez obie strony, zostaje on przekazany wojewodzie wraz z szacowanymi kosztami jego realizacji. Wojewoda po akceptacji treści programu przekazuje środki na jego realizację. Ze strony powiatowego centrum pomocy rodzinie wsparcia udziela wyznaczony pracownik tej instytucji, który następnie działa jako realizator programu. Drugą stroną umowy może być tylko i wyłącznie cudzoziemiec, który spełnia wymogi opisane w ustawie, czyli posiada status uchodźcy lub uzyskał ochronę międzynarodową. W praktyce oznacza to więc, iż tylko cudzoziemiec, który złożył wniosek o udzielenie ochrony międzynarodowej, spełnił wymagania formalne, a następnie uzyskał decyzję o uzyskaniu tejże ochrony, bądź nadaniu statusu uchodźcy ma prawo do skorzystania z pomocy społecznej w formie indywidualnego programu integracji.

Powiatowe centrum pomocy rodzinie współdziała z wojewodą oraz gminą, aby uzyskać możliwość zamieszkania cudzoziemca w powiecie, w miarę możliwości w miejscu wskazanym przez samego zainteresowanego. W przypadku wskazania 
miejsca zamieszkania przez wojewodę, cudzoziemiec zobowiązany jest do zamieszkania w nim, a rezygnacja w okresie trwania programu jest jednoznaczna z rezygnacją udziału w programie. Wyjątkiem jest zmiana wyznaczonego miejsca zamieszkania w szczególnych przypadkach, które art. 94 ustawy z dnia 12 marca 2004 r. o pomocy społecznej definiuje jako:

- uzyskanie lokum na terenie innego powiatu;

- podjęcie pracy zawodowej wraz z możliwością zamieszkania w innym powiecie;

- połączenie rodzin cudzoziemców;

- w sytuacji, gdzie konieczne będzie objęcie specjalistycznym leczeniem, które wymaga zmiany miejsca zamieszkania osoby bądź członka jego rodziny (Dz. U. z 2019 r. poz. 1690).

W przypadku chęci lub konieczności zmiany miejsca zamieszkania, na cudzoziemcu spoczywa obowiązek złożenia oświadczenia oraz dokumentów poświadczających w centrum pomocy. Jeżeli następuje zmiana miejsca zamieszkania cudzoziemca poza powiat, to starosta właściwy w poprzednim miejscu zamieszkania osoby zawiadamia o tym starostę w nowym miejscu zamieszkania. Jeśli następuje zmiana województwa, wówczas ówczesny starosta powiada o tym wojewodę z nowego województwa (Dz. U. z 2019 r. poz. 1690).

Prawo przewiduje możliwość przerwania udzielania wsparcia. Powodami, dla których może nastąpić wstrzymanie udzielania świadczenia są:

- podanie fałszywych informacji na temat swojej sytuacji życiowej - do czasu wyjaśnienia;

- niewywiązywanie się ze zobowiązań i ustaleń przyjętych w programie, a w tym nieuczęszczanie na zajęcia z nauki języka polskiego bez ważnej przyczyny przez okres do $30 \mathrm{dni}$;

- wykorzystywanie pomocy w sposób inny niż zgodny z celem, na jaki została przyznana, przez okres do $30 \mathrm{dni}$;

- w sytuacji 30 dni pobytu w zakładzie opieki zdrowotnej, do czasu opuszczenia placówki;

- wszczęcia postępowania karnego przeciwko osobie, do czasu prawomocnego zakończenia (Dz. U. z 2019 r. poz. 1690, art. 95).

Jeżeli którakolwiek z przesłanek ustanie, pracownik socjalny realizujący program zwraca się do kierownika jednostki o przywrócenie pomocy, która została wstrzymana. Możliwe jest całkowite uchylenie pomocy w przypadku, gdy po zakończeniu okresu wstrzymania pomocy przyczyny nie ustąpiły. Natychmiastowe całkowite uchylenie pomocy następuje, jeżeli cudzoziemiec:

- ponownie dopuszcza się zachowań i działań, które powodują wstrzymanie pomocy;

- osoba została pozbawiona statusu uchodźcy bądź cofnięto jej pozwolenie na pobyt czasowy lub ochronę uzupełniająca; 
- osoba została ukarana wyrokiem prawomocnym sądu za przestępstwo, które zostało popełnione w sposób umyślny (Dz. U. z 2019 r. poz. 1690, art. 95).

Jeżeli pomocą $\mathrm{w}$ ramach indywidualnego programu integracji były objęte inne osoby, to pomoc ta jest kontynuowana do momentu zakończenia czasu trwania programu lub też wydaje się odrębną decyzję, na mocy której przyznaje się pomoc i kontynuację indywidualnego programu wsparcia cudzoziemca (Dz. U. z 2019 r. poz. 1690, art. 95).

\section{Realizacja indywidualnych programów integracji w Polsce}

O przystąpienie do programu ubiegać się może cudzoziemiec, który uzyskał status uchodźcy lub ochronę uzupełniają lub też zezwolenie na pobyt czasowy na warunkach określonych w art. 159 ust. 1 pkt 1 lit. c lub d ustawy z dnia 12 grudnia 2013 r. ocudzoziemcach (Dz. U. z 2019 r. poz. 1690, art. 91, pkt 1). Aby skorzystać $\mathrm{z}$ programu, imigrant składa pisemny wniosek $\mathrm{w}$ powiatowym centrum pomocy rodzinie, w terminie do 60 dni od daty uzyskania pozytywnej decyzji w sprawie udzielenia ochrony międzynarodowej (Dz. U. z 2019 r. poz. 1690, art. 91, pkt 3). Zainteresowany zobligowany jest do złożenia wniosku w formie pisemnej, zawierającego deklarację o zamiarze zamieszkania na określonym terenie; oświadczenie, iż nie zwrócił się z podobnym wnioskiem $\mathrm{w}$ innym województwie oraz oświadczenie o gotowości do udziału w uzgodnionym indywidualnym programie integracji (Dz. U. z 2019 r. poz. 1690, art. 91, pkt 4). Cudzoziemcy oczekujący na decyzję w sprawie udzielenia ochrony międzynarodowej w formie statusu uchodźcy, ochrony uzupełniającej lub zezwolenia na pobyt czasowy mogą przebywać w ośrodku dla cudzoziemców bądź otrzymywać świadczenie pieniężne w zamian. Dla obcokrajowców, którzy po przekroczeniu granicy na decyzję oczekiwali w ośrodku dla cudzoziemców, indywidualny program integracji stanowić może kontynuację profesjonalnego wsparcia socjalnego, prawnego czy psychicznego uzyskanego w jednym z ośrodków dla cudzoziemców.

Praca z cudzoziemcami wymaga od pracowników socjalnych szczególnej uwagi i ostrożności, ze względu na możliwe traumatyczne przeżycia klienta. Aby praca z uchodźczynią i uchodźcą była efektywna i przynosiła pożądany efekt, warto przede wszystkim zidentyfikować sytuację takiej osoby, a więc zapytać o to skąd przybyła, jak dawno temu znalazła się w Polsce oraz jak wyglądała ta droga. Osoby te niemal zawsze mają za sobą bardzo trudne przeżycia, nierzadko traumatyczne, z którymi poradzenie sobie bez pomocy specjalisty może być wręcz niemożliwe. Bardzo ważna jest tutaj rola pracownika socjalnego, okazanie zrozumienia i też poufności w całej sytuacji, a w razie potrzeby zapewnienie adekwatnej do potrzeb 
pomocy. Wśród reakcji, jakie mogą nieść za sobą traumatyczne przeżycia uchodźców, są m.in.: ataki paniki; niepokój, lęk; obniżenie nastroju i stany depresyjne; bezsenność; nieufność; irytacja; agresja; zaburzenia odżywania; smutek (Azarewicz i in., 2016, s. 38-39). Pomimo iż pracownik socjalny nie jest psychologiem ani nie posiada uprawnień do prowadzenia psychoterapii, powinien w tej sytuacji wykazać się dużym profesjonalizmem i zrobić wszystko, aby nie doprowadzić do powtórnej traumatyzacji. Obowiązkiem jest zadbanie o to, aby osoba czuła się swobodnie pomimo różnic kulturowych i całkiem innej rzeczywistości. Pracownik socjalny jest osobą pierwszego kontaktu i często jest osobą, której powierzane są historie trudnych przeżyć.

Łącznie w latach 2012-2016 zrealizowano 808 programów (MRPiPS 20122016), jednak Ministerstwo Rodziny, Pracy i Polityki Społecznej dotychczas nie opublikowało danych z kolejnych lat. W latach 2012-2014 IPI były realizowane na terenie 51 powiatów (NIK, 2014, s. 37). Od 2012 r. tendencja realizacji programów była rosnąca aż do 2015 roku, gdzie osiągnęła liczbę 247 programów, spadając do liczby 172 programów w 2016 roku (MRPiPS 2012-2016). Dla porównania, w 2015 roku ponad 600 cudzoziemców uzyskało pozytywną decyzję w sprawie udzielenia ochrony międzynarodowej w Polsce (UdSC, 2016). Oznacza to, że niecała $1 / 3$ uprawionych skorzystała tego roku z pomocy w formie indywidualnego programu integracji. Wraz ze wzrostem ilości przeprowadzonych programów, wzrastała też ilość programów, które zostały ukończone - oznacza to, iż uchodźca pobierał świadczenie przez okres 12 miesięcy. W 2013 r. zanotowano najniższą liczbę ukończonych programów - było ich 42 (MRPiPS, 2013), a w 2016 najwyższą - było ich 135 (MRPiPS, 2015). Łącznie w latach 2012-2016 zakończonych zostało 443 programy. W latach 2012-2015 IPI zostało objęte ponad 600 rodzin uchodźców z całego świata, m.in. z Syrii, Rosji, Ukrainy, Kirgistanu, Kazachstanu, Białorusi, Tadżykistanu, a nawet z Korei Północnej i Sri Lanki, czy też tzw. bezpaństwowców. Wśród narodowości, które co roku realizują wysoką ilość IPI, są obywatele krajów wschodnich, takich jak Białoruś, Rosja, Afganistan czy Irak (MRPiPS 2013-2016).

Przeprowadzone zostały badania jakościowe na grupie 19 pracowników socjalnych z 23 powiatowych centr pomocy rodzinie w całej Polsce. Najwięcej ankietowanych pochodziło z województw pomorskiego oraz mazowieckiego. Badani byli w wieku od 25 do 56 lat, a ich staż pracy w powiatowych centrach pomocy rodzinie wynosił od 1 roku do 35 lat.

Autorka w swoich badaniach eksplorowała m.in. tematykę przygotowania pracowników socjalnych do pracy z cudzoziemcami, problemów i trudności napotykanych w czasie pracy z uchodźcami, skalę praktycznego realizowania programów oraz przydatność i skuteczność realizowanych indywidualnych programów integra- 
cji. Odnosząc się do wniosków wynikających z przeprowadzonego badania, należy mieć na uwadze brak ogólnodostępnych danych dotyczących tego, które z instytucji realizują to zadanie oraz fakt, iż ostatnie dane statystyczne dotyczące realizacji programów integracji cudzoziemców zostały udostępnione przez Ministerstwo Rodziny, Pracy i Polityki Społecznej w 2016 roku. Od tego czasu nie zostały podane do informacji publicznej raporty z realizacji programów w Polsce.

Wyniki wspomnianych badań wskazują, iż $2 / 3$ ankietowanych ma doświadczenie w pracy socjalnej z cudzoziemcami, z kolei $1 / 3$ wszystkich ankietowanych ocenia swoje przygotowanie do pracy z uchodźcami jako ani dobre, ani złe. Zdecydowana większość nigdy nie uczestniczyła w szkoleniach przygotowujących do pracy z cudzoziemcami. Ankietowani, którzy odbyli takie szkolenia, zrealizowali je w latach 2018-2020 i w większości oceniają je jako przydatne. Ponad 2/3 wszystkich badanych odczuwa potrzebę uczestnictwa $\mathrm{w}$ nowych szkoleniach $\mathrm{z}$ zakresu udzielania wsparcia uchodźcom. Ponad połowa respondentów zna języki obce umożliwiające komunikację z cudzoziemcami. Najczęściej wskazywane języki to angielski oraz rosyjski. Większość ankietowanych napotyka problemy i trudności w pracy socjalnej z cudzoziemcami. Wśród najczęściej wymienianych są niechęć uchodźców do współpracy z pracownikiem socjalnym oraz bariera językowa. Pomimo znajomości języków obcych przez większość ankietowanych, wskazali oni barierę językową. Można przypuszczać, iż wynika to ze zbyt słabej znajomości języka obcego lub też z nieznajomości języków, którymi posługują się imigranci. Możliwe jest także, iż problem stanowi fakt, że cudzoziemcy mogą komunikować się tylko z wybranymi pracownikami. Ankietowani wskazali, iż z pomocy w formie IPI najczęściej korzystają rodziny z dziećmi, w przedziale wiekowym 31-40 lat. Badania wykazały, iż formą pomocy, którą cudzoziemcy wybierają najrzadziej, to pomoc niepieniężna, w formie wsparcia w poszukiwaniu mieszkania lub nauki języka polskiego. Z kolei najczęściej wybieraną formą pomocy jest wsparcie finansowe. Niecała połowa badanych ocenia warunki udzielania wsparcia w programie za wystarczające, a około 1/3 wskazała, iż trudno powiedzieć. Zdecydowana większość, bo $2 / 3$ badanych nie widzi konieczności wprowadzania zmian w programach. Wśród ankietowanych, którzy opowiedzieli się za wprowadzeniem zmian najczęstszą sugestią było dostosowanie czasu trwania IPI do indywidualnych potrzeb odbiorcy. Ponad połowa respondentów uważa, iż cudzoziemcy przebywający w Polsce powinni się adaptować oraz integrować ze środowiskiem lokalnym. Kilku ankietowanych zwróciło uwagę, iż takie działania, które mają za cel kreowanie pozytywnych postaw społeczeństwa w stosunku do cudzoziemców, nie oddają charakteru programów, a one same są zbyt krótkie, by rozszerzyć je o działania związane z budowaniem postaw społeczeństwa. Niektórzy wskazali też na działania o charakterze integracji społeczeństwa z cudzoziemcami, spotkania sąsiedzkie i poznawanie odmiennych kultur. (Parcia, 2020, s. 78). 
System pomocy cudzoziemcom w Polsce jest nadal słabo rozwinięty. Świadczy o tym bardzo niski odsetek pozytywnych decyzji w sprawie udzielania ochrony międzynarodowej cudzoziemcom, skala ta wynosi kilkaset osób na kilkanaście tysięcy wniosków rocznie. Wpływają na to długie i zawiłe procedury prawne, tzn. długi czas oczekiwania na decyzję, podczas którego cudzoziemiec może zdecydować się na pobyt w ośrodku dla cudzoziemców lub pobyt w kraju na własną rękę. W obu przypadkach uchodźca może liczyć tylko na skromną pomoc materialną i pieniężną od państwa. Sytuacji nie ułatwia także stosunek społeczeństwa do cudzoziemców. Od 2015 do 2018 roku coraz więcej osób było całkowicie przeciwnych przyjmowaniu uchodźców do Polski i pomaganiu im w jakiejkolwiek formie. Coraz mniej osób opowiadało się za przyjęciem ich i pozwoleniem na osiedlenie się. Jednocześnie wzrosło przekonanie, iż powinniśmy przyjmować uchodźców i udzielać im wsparcia do czasu, kiedy sytuacja w ich kraju nie ustabilizuje się. Według wniosku z raportu CBOS „Polacy nie są otwarci na przyjmowanie uchodźców z państw objętych konfliktami zbrojnymi, choć skłonność do udzielenia im chociaż czasowego schronienia zależy od tego, z jakiego kraju pochodzą" (CBOS, 2018). Według badań Polacy wyrażają większą niechęć do przyjmowania cudzoziemców z Afryki i Bliskiego Wschodu niż z Ukrainy. W 2017 roku aż 72\% ankietowanych Polaków wyraziło niechęć i sprzeciw przeciwko przyjmowaniu uchodźców z Bliskiego Wschodu i Afryki (CBOS, 2018). W kwestii cudzoziemców, którzy pochodzą z terenów dotkniętych konfliktem zbrojnym w Ukrainie, aż 56\% respondentów wyraziło chęć przyjmowania ich w Polsce, a stanowczy sprzeciw wyraziło $36 \%$ badanych (CBOS, 2018).

\section{Podsumowanie}

Podsumowując powyższe rozważania należy stwierdzić, iż indywidualny program integracji jest $\mathrm{w}$ niewielkim stopniu wykorzystywaną i stosowaną formą pomocy cudzoziemcom w Polsce. Tylko niewielki odsetek cudzoziemców otrzymuje decyzję pozytywną - w 2019 roku na ponad 4000 złożonych wniosków tylko około 100 cudzoziemców uzyskało ochronę międzynarodową. Oznacza to, iż liczba realizowanych programów integracji cały czas maleje, ponieważ niewielka ilość cudzoziemców jest uprawniona do skorzystania z tej formy pomocy. Ocena faktycznego przeprowadzania programów integracji jest też utrudniona ze względu na brak ogólnodostępnych danych dotyczących tego, które z instytucji realizują to zadanie. Biorąc pod uwagę powyższe dane można stwierdzić, iż liczba realizowanych programów integracji cudzoziemców w Polsce jest niewielka, a dane statystyczne dostępne są tylko sprzed kilku lat, co utrudnia dostęp instytucji realizujących to zadanie. 
Podobnie jest także w kwestii literatury przedmiotu. Niewielka ilość pozycji naukowych pozwala zasugerować potrzebę rozszerzenia badań dotyczących programów integracji dla cudzoziemców. Wyniki badań sugerują, iż programy są realizowane tylko w niektórych powiatowych centrach pomocy rodzinie. Przedstawione wyniki badania wskazują na problem niedostatecznego przygotowania pracowników socjalnych do pracy z cudzoziemcami. Dodatkowo, aż dwie trzecie odpowiedziało, że odczuwają silną lub umiarkowaną potrzebę uczestnictwa w nowych szkoleniach i kursach dotyczących pracy z cudzoziemcami. To również pokazuje, iż sami pracownicy czują się niedostatecznie przygotowani i chcieliby podnieść swoje kwalifikacje zawodowe w obszarze pracy z uchodźcami.

Odwołując się do powyższych rozważań można stwierdzić, iż ważne jest, aby zarówno w sferze naukowej, jak i praktycznej pogłębiać temat realizacji indywidualnych programów integracji oraz profesjonalnego wspierania cudzoziemców.

\section{Bibliografia}

Azarewicz A., Filipowicz A., Hakiel A., Kocowska K., Mandel M. (2016). Uchodźczynie i uchodźcy. Przewodnik do pracy socjalnej i asystentury środowiskowej. Wrocław: NOMADA Stowarzyszenie na Rzecz Integracji Społeczeństwa Wielokulturowego.

Główny Urząd Statystyczny. Populacja cudzoziemców w Polsce w czasie COVID-19. Pobrano z: https://stat.gov.pl/statystyki-eksperymentalne/kapital-ludzki/populacja-91 cudzoziemcow-w-polsce-w-czasie-covid-19,12,1.html (dostęp: 23.08.2020).

Kawczyńska-Butrym Z., (2009). Migracje: wybrane zagadnienia. Lublin: Wydawnictwo Uniwersytetu Marii Curie-Skłodowskiej.

Konwencja dotycząca statusu uchodźców sporządzona w Genewie dnia 28 lipca 1951 r., Dz. U. z 1991, nr 119, poz. 515.

Misztal K. (2013). Indywidualny program integracji jako forma realizacji "pomocy dla cudzoziemca" - wybrane zagadnienia. Wrocław: Prawnicza i Ekonomiczna Biblioteka Cyfrowa.

Najwyższa Izba Kontroli. Pomoc spoteczna dla uchodźców informacja o wynikach kontroli. Pobrano z: https://www.nik.gov.pl/plik/id,10216,vp,12539.pdf (dostęp: 11.10.2020).

Parcia B. (2020). Indywidualne programy integracji jako forma wsparcia cudzoziemców. Nieopublikowana praca magisterska, Uniwersytet Pedagogiczny w Krakowie.

Sprawozdanie Ministerstwa Pracy i Polityki Społecznej ze świadczeń z pomocy społecznej udzielonym cudzoziemcom w 2013 roku na wsparcie indywidualnych programów integracji. Pobrano z: https://archiwum.mpips.gov.pl/gfx/mpips/ 
userfiles/_public/1_NOWA\%20STRONA/Pomoc\%20spoleczna/cudzoziemcy/Sprawozdanie\%202013.pdf (dostęp: 23.12.2019).

Sprawozdanie Ministerstwa Pracy i Polityki Społecznej ze świadczeń z pomocy społecznej udzielonym cudzoziemcom w 2014 roku na wsparcie indywidualnych programów integracji. Pobrano z: https://archiwum.mpips.gov.pl/gfx/mpips/ userfiles/_public/1_NOWA\%20STRONA/Pomoc\%20spoleczna/cudzoziemcy/2014\%20-92\%20pomoc\%20w\%20PCPR\%20i\%20OPS\%20dla\%20cudzoziemcow.pdf (dostęp: 23.12.2019).

Sprawozdanie Ministerstwa Pracy i Polityki Społecznej ze świadczeń z pomocy społecznej udzielonym cudzoziemcom w 2015 roku na wsparcie indywidualnych programów integracji. Pobrano z: https://archiwum.mpips.gov.pl/gfx/mpips/ userfiles/_public/1_NOWA\%20STRONA/Pomoc\%20spoleczna/cudzoziemcy/Sprawozdanie\%20pomoc\%20cudzozie mcom\%202015.pdf (dostęp: 23.12.2019).

Sprawozdanie Ministerstwa Pracy i Polityki Społecznej ze świadczeń z pomocy społecznej udzielonym cudzoziemcom w 2016 roku na wsparcie indywidualnych programów integracji. Pobrano z: https://archiwum.mpips.gov.pl/gfx/mpips/ userfiles/_public/1_NOWA\%20STRONA/Pomoc\%20spoleczna/cudzoziemcy/Sprawozdanie\%202016.pdf (dostęp: 23.12.2019).

Ustawa z dnia 12 grudnia 2013 r. o cudzoziemcach, Dz. U. z 2013 r., poz. 1650.

Ustawa z dnia 12 marca 2004 r. o pomocy społecznej, Dz. U. z 2019 r. poz. 1690. Ustawa z dnia 13 czerwca 2003 roku o udzielaniu cudzoziemcom ochrony na terytorium Rzeczypospolitej Polskiej, Dz. U. z 2003 r., nr 128, poz. 1176.

\title{
The actions of District Family Support Centres within the scope of support for foreigners
}

\begin{abstract}
This article refers to the subject of individual integration programs for foreigners in Poland, which is rarely described in the literature. It pertains to theoretical aspects of the terms of foreigners and refugees. The issue of legal regulations on applying for and administrating international protection in Poland as well as entitlement to receive social welfare benefits are presented. The article displays the results of research conducted among social workers from selected District Family Support Centers. In the summary, the author indicates conclusions regarding the implementation of individual integration programs as a form of aid for foreigners.
\end{abstract}

Keywords: foreigners, refugees, individual integration programs. 